\title{
Pauta, público, princípios e precedentes: condicionantes e consequências da prática deliberativa do $\mathrm{STF}^{1-2}$
}

\author{
Agenda, public, principles and precedents: constraints and consequences of the \\ deliberative practice in the Brazilian Supreme Court
}

\author{
Virgílio Afonso da Silva ${ }^{3}$ \\ Universidade de São Paulo (São Paulo, SP, Brasil) \\ ORCID: https://orcid.org/0000-0002-6063-4545 \\ E-mail: vas@usp.br
}

\section{Resuimo}

A deliberação em um tribunal ocorre em momentos específicos. Mas há fatores que podem influenciar esses momentos deliberativos que precedem a deliberação propriamente dita. E a forma como um tribunal delibera e decide também tem efeitos que se protraem no tempo e influenciam deliberações futuras. Este artigo ocupa-se de algumas dessas condicionantes e consequências da prática deliberativa e decisória do Supremo Tribunal Federal (STF), como a definição da pauta, os princípios e métodos de interpretação constitucional, a formação de um sistema de precedentes vinculantes, as audiências públicas e a relação do tribunal com seu público. Este é o último de uma série de artigos que expõem os resultados de uma pesquisa que pretendeu compreender o que os próprios ministros do STF pensam da prática deliberativa e decisória desse tribunal.

\footnotetext{
${ }^{1}$ SILVA, Virgílio Afonso da. Pauta, público, princípios e precedentes: condicionantes e consequências da prática deliberativa do STF. Suprema: revista de estudos constitucionais, Brasília, v. 1, n. 1, p. 22-56, jan./jun. 2021.

${ }^{2}$ A pesquisa que deu origem a este artigo teve financiamento da Fundação de Amparo à Pesquisa do Estado de São Paulo (processo Fapesp 2011/01066-0). Uma versão preliminar do texto foi debatida no seminário de pesquisa do grupo constituição, política ers instituições, da Faculdade de Direito da USP. Agradeço aos participantes, especialmente a Amanda Melillo de Matos, Ana Laura Barbosa, Arthur El Horr, Arthur Guerra Filho, Artur Pericles Lima Monteiro, Bianca Villas Bôas, Camilla Gomes, Conrado Hübner Mendes, Cristiano de Jesus Pereira Nascimento, Julia Cani, Lívia Gil Guimarães, Luiz Fernando Gomes Esteves, Maysa Cortez, Meliza Franco e Pedro Marques Neto, os comentários que ajudaram a melhorar o texto. Gostaria também de, mais uma vez, agradecer a Guilherme Benages Alcantara e Tatiana Alvim a hospitalidade em Brasília durante as minhas visitas ao Supremo Tribunal Federal. Por fim, eu agradeço também aos ministros do STF que concordaram em participar deste projeto.
}

${ }^{3}$ Professor Titular de Direito Constitucional na Faculdade de Direito da Universidade de São Paulo. Currículo Lattes: https:// lattes.cnpq.br/1710445306180570. 


\section{Palavras-chave}

Supremo Tribunal Federal; deliberação; pauta; precedentes; audiências públicas.

\section{Sumário}

1. Introdução. 2. A pesquisa e sua metodologia. 3. Um conceito de deliberação. 4. Deliberação e legitimidade do tribunal. 5. A definição da pauta: centralização e impactos na deliberação. 6. Princípios e métodos de interpretação constitucional. 7. O processo decisório e a possibilidade de precedentes vinculantes. 8. Audiências públicas: inovação, formalismo e pouca participação. 9. O STF e seu público. 10. Antigos ministros: algo mudou? 11. Conclusão.

\section{Abstract}

Deliberation in courts occurs at specific moments. Nevertheless, some pre-deliberation factors may influence the deliberative dynamics. Additionally, the decision-making rules and outcomes may impact future deliberations. This article aims to analyze some of the constraints and consequences of the deliberative practice and decisionmaking process of the Brazilian Supreme Court, such as agenda-setting, principles and methods of constitutional interpretation, system of binding precedents, public hearings, and the relationship between the court and its audience. This is the last of a series of articles that present the results of a research that sought to understand what the justices of the Brazilian Supreme Court themselves think of the deliberative practice and decision-making process of that court.

\section{Keywords}

Brazilian Supreme Court; deliberation; agenda-setting; precedent; public hearings.

\section{Contents}

1. Introduction. 2. The research and its methodology. 3. A concept of deliberation. 4. Deliberation and legitimacy of the court. 5. Agenda-setting power: centralization and impacts on deliberation. 6. Principles and methods of constitutional interpretation. 7. Decision-making process and the possibility of binding precedents. 8. Public hearings: innovation, formalism and low participation. 9. The Brazilian Supreme Court and its audience. 10. Former justices: did anything change? 11. Conclusion. 


\section{Introdução}

A deliberação em um tribunal ocorre em momentos específicos. Em geral, ela ocorre de forma oral em uma sessão de deliberação, que pode também ser, mas não necessariamente é, uma sessão de julgamento. A deliberação pode também ocorrer de forma escrita, por meio da circulação de memorandos entre os integrantes do tribunal, embora essa prática seja menos frequente. Mas há fatores que podem influenciar esses momentos deliberativos que precedem a deliberação propriamente dita. A escolha do relator de uma ação ou recurso e a definição da pauta das sessões de julgamento são dois exemplos triviais, existentes em quase todos os tribunais, mas há outros que são peculiares ao STF, como a realização de audiências públicas em alguns casos.

A forma como um tribunal delibera e decide também tem efeitos que se protraem no tempo e influenciam deliberações futuras. A possibilidade de criação de um sistema de precedentes vinculantes é um exemplo disso. Determinados processos deliberativos e decisórios podem ser propensos a produzir decisões menos fragmentadas e, assim, facilitar a identificação não apenas de resultados, mas também de argumentos vinculantes.

Este artigo é o último de uma série cujo objetivo era apresentar os resultados de uma pesquisa que pretendia compreender o que os próprios ministros do STF pensam da prática deliberativa e decisória desse tribunal. Ao contrário dos artigos anteriores, que tinham um tema central que guiava todo o texto - a forma de deliberar, o papel do voto do relator, a função dos votos divergentes ou a transmissão das sessões de julgamento pela $\mathrm{TV}^{4}$-, este último reúne temas que não têm necessariamente uma relação entre si. O que os une é apenas a possibilidade de terem alguma relação com a deliberação e o processo decisório do tribunal.

Após uma exposição sobre a metodologia da pesquisa, feita no tópico a seguir, exponho, no tópico 3, o conceito de deliberação que serviu de base às entrevistas. O tópico 4 dedica-se a explorar uma possível (mas não necessária) relação entre forma de deliberar, qualidade das decisões e legitimidade do controle judicial de constitucionalidade. O tópico 5 aborda um tema que vem chamando cada vez mais a atenção de juristas e cientistas políticos, que é a pauta de julgamentos do tribunal. A pergunta central nesse âmbito diz respeito à influência da definição da pauta de julgamento na dinâmica deliberativa. No tópico seguinte será abordado um tema que tradicionalmente recebe muita atenção da literatura constitucional e pouquíssima do próprio tribunal: os princípios e métodos de interpretação constitucional. Não

${ }^{4}$ Cf., respectivamente, Silva (2015a, 2015b, 2017, 2018). 
se trata, aqui também, de um debate sobre princípios e métodos em si, mas sobre os efeitos que um processo decisório muitas vezes individualizado pode ter na coerência metodológica do tribunal. Essa individualização do processo decisório é também o cerne do tópico 7, que aborda as possibilidades de construção de um sistema de precedentes vinculantes em um contexto de decisões que são muitas vezes a agregação de argumentos distintos e, em alguns casos, incompatíveis entre si. Os dois tópicos seguintes são dedicados à relação do tribunal com agentes externos. $\mathrm{O}$ tópico 8 explora a realização de audiências públicas e seu impacto na prática deliberativa e decisória do STF. Já o tópico 9 pretende expor como os ministros lidam com seu público quando da redação de seus votos. O tópico 10 expõe, de forma muito breve, a impressão que os ministros aposentados têm sobre o processo deliberativo e decisório do tribunal após suas aposentadorias. O tópico 11 é a conclusão do artigo.

\section{A pesquisa e sua metodologia}

Como mencionado acima, este artigo sistematiza parte dos resultados de uma pesquisa mais ampla sobre a prática deliberativa no STF. ${ }^{5}$ Essa pesquisa baseou-se sobretudo em entrevistas com ministros do STF. Essas entrevistas não tinham o objetivo de saber o que se passa no interior da sala de julgamento, já que as sessões do STF são públicas e suas sessões plenárias, transmitidas ao vivo. Seu objetivo era compreender como os próprios ministros do STF encaram o processo deliberativo do qual participam.

Como a forma de deliberação e decisão no STF, em seus aspectos mais gerais, é a mesma há décadas, cada novo ministro ou ministra se vê, sem grandes possibilidades de variação, compelido a seguir o rito deliberativo ditado pela tradição e pelo regimento interno. ${ }^{6}$ Isso não significa, contudo, que todos encarem seu papel individual em uma instituição coletiva como o STF da mesma forma. Em outras palavras: as informações a que temos acesso por meio da extrema publicidade a que estão submetidas as

\footnotetext{
${ }^{5} \mathrm{O}$ texto desta seção, que resume a metodologia e os objetivos da pesquisa sobre deliberação no STF, é repetido em todos os artigos que expõem os resultados dessa pesquisa (ver artigos mencionados na nota anterior).

${ }^{6}$ Essa afirmação não implica que nada tenha mudado. É certo que muita coisa mudou, mas o momento deliberativo continua o mesmo (a sessão de julgamento) e a forma de participação nesse momento (sequencial, sempre na mesma ordem) também. O processo decisório também continua o mesmo (seriatim, sem uma opinião da corte). Em momento posterior à realização das entrevistas, duas mudanças importantes alteraram essa configuração básica: a prática cada vez mais difundida de as decisões estabelecerem teses, que em alguma medida podem desempenhar um papel semelhante ao que a "opinião da corte" desempenha em tribunais de alguns países; e a ampliação do julgamento virtual, no qual há ainda menos interação entre ministras e ministros, uma outra forma de definição de pauta e, sobretudo, a mitigação completa da sequência predefinida para a manifestação dos ministros. Embora sejam mudanças recentes e, portanto, não façam parte do pano de fundo das entrevistas, algumas referências a elas serão feitas ao longo deste artigo, sobretudo na conclusão.
} 
atividades dos ministros do STF não são suficientes para compreender o papel que os próprios ministros pretendem desempenhar, tampouco nos dizem o que cada ministro pensa da atual forma de decisão nesse tribunal. Não é factível supor que todos tenham a mesma compreensão sobre o papel da colegialidade e dos votos divergentes, sobre a função do relator, sobre a importância de um pedido de vista, ou sobre os efeitos da extrema publicidade na prática deliberativa do STF.

Essa parece ser uma lacuna na produção acadêmica sobre o STF. De um lado, temos acesso a uma quantidade cada vez maior de informações (via banco de dados na internet, TV Justiça, canais do STF no YouTube e no Twitter), de outro, nem sempre sabemos o que aqueles que produzem essas informações (os ministros e ministras) pensam sobre a forma como elas são produzidas. ${ }^{7}$ As entrevistas tinham como função fornecer subsídios para conhecer melhor a prática deliberativa do STF a partir de um material não disponível até então. ${ }^{8}$

De setembro de 2011 a agosto de 2013, dezessete ministros (na ativa ou aposentados) foram entrevistados. ${ }^{9}$ As entrevistas eram estruturadas (isto é, iguais para todos os ministros) e compostas de 36 questões, algumas com subquestões, sobre os seguintes assuntos: papel do ministro relator, votos divergentes, dinâmica da deliberação, relação entre deliberação e legitimidade do controle de constitucionalidade, poder de agenda e deliberação, métodos de interpretação constitucional, valor do consenso no processo decisório, interrupções durante o processo deliberativo, colegialidade, publicidade, transmissão das sessões pela TV, relação entre deliberação e precedentes judiciais, e deliberação e opinião pública. Cada entrevista durou em média uma hora e quinze minutos. A entrevista mais longa durou 2 horas e 45 minutos, a mais curta, 45 minutos. As questões não foram enviadas

\footnotetext{
${ }^{7}$ Como ocorre em qualquer entrevista, é impossível ter certeza de que as respostas dos ministros foram sempre sinceras. Por definição, essa ressalva está embutida na afirmação feita no texto, segundo a qual as entrevistas permitem que conheçamos o que os ministros pensam sobre a prática deliberativa do STF. As dúvidas sobre a sinceridade nas respostas não têm qualquer relação com desonestidade. Os ministros do STF são pessoas públicas que ocupam posições importantíssimas no sistema constitucional brasileiro. Como qualquer pessoa pública em posição semelhante, eles naturalmente constroem e mantêm uma imagem pública. $\mathrm{O}$ sentido das respostas às perguntas feitas nas entrevistas (e em qualquer entrevista) só pode ser compreendido nesse contexto. A decisão por publicar os resultados da pesquisa sem identificar os ministros, que será explicada adiante no texto, tinha como objetivo atenuar em alguma medida possíveis discrepâncias entre o discurso e a prática deliberativa de cada ministro.
${ }^{8}$ Após a conclusão da pesquisa, a Escola de Direito da Fundação Getúlio Vargas no Rio de Janeiro iniciou um projeto chamado "História Oral do Supremo", no âmbito do qual vários ministros e ministras do STF foram entrevistados (ver https:// historiaoraldosupremo.fgv.br). Embora com um escopo temático mais amplo, essas entrevistas também contêm algumas perguntas relacionadas ao processo deliberativo no tribunal.

${ }^{9}$ Como se percebe, as últimas entrevistas foram realizadas já há algum tempo. Várias razões atrasaram a sistematização e a publicação deste artigo com os últimos resultados da pesquisa. No entanto, é importante ressaltar que, desde a realização da última entrevista, em meados de 2013, apenas três novos ministros foram nomeados para o STF: Edson Fachin (2015), Alexandre de Moraes (2017) e Nunes Marques (2020).
} 
previamente aos ministros e todas as entrevistas ocorreram de forma presencial. Todas as entrevistas foram gravadas e depois transcritas. ${ }^{10}$

Antes de iniciar cada entrevista, foi assegurado ao entrevistado que as informações seriam usadas de forma anônima. Como o objetivo da pesquisa não é expor a opinião individual dos ministros, mas construir um cenário coletivo a partir de visões individuais, o anonimato nas declarações não compromete os resultados. Pelo contrário, ele tem o potencial de deixar os ministros à vontade para expor de forma mais sincera suas opiniões. ${ }^{11}$

Para manter o anonimato, os nomes dos ministros foram substituídos por letras. Embora não haja nenhuma ordem reconhecível nessas letras, uma divisão clara foi feita: as letras A a I representam ministros no exercício da função (no momento da entrevista), enquanto as letras $\mathrm{N}$ a $\mathrm{U}$ indicam ministros que, ao tempo das entrevistas, já estavam aposentados. Ao longo do texto, não faço distinção entre ministros na ativa e antigos ministros, a não ser nos casos em que isso tenha me parecido conveniente, para deixar alguma contraposição mais clara. De qualquer forma, é sempre possível saber se se trata de um antigo ministro ou de um ministro na ativa com base nas letras.

Como regra geral, a despeito de suas agendas congestionadas, os ministros foram extremamente receptivos aos objetivos da pesquisa. Em vários casos, dispuseram-se até mesmo a fazer mais de um encontro para que as entrevistas pudessem ser feitas no ritmo ideal. Como foram poucos os ministros que se recusaram a conversar, é possível supor que os resultados obtidos têm um grande potencial explicativo sobre a prática deliberativa no STF. ${ }^{12}$

Este e os outros artigos que expõem os resultados da pesquisa não têm o perfil tradicional de um artigo acadêmico na área jurídica. ${ }^{13}$ Não é objetivo deste texto nem defender normativamente uma tese sobre o processo deliberativo no STF, nem ser descritivo a partir de uma perspectiva exclusivamente externa, tampouco fazer uma revisão de literatura sobre o tema investigado. $\mathrm{O}$ que se pretende, como foi delineado

\footnotetext{
${ }^{10}$ As perguntas relacionadas aos temas tratados neste artigo estão transcritas no anexo.

${ }^{11}$ Essa metodologia foi inspirada na metodologia usada por Uwe Kranenpohl em trabalho sobre o Tribunal Constitucional alemão. Cf. Kranenpohl (2010). Não há consenso na literatura sobre os efeitos da confidencialidade. Ainda assim, Krumpal (2011, p. 2036) sustenta que a garantia de confidencialidade tende a "reduzir os receios dos participantes e aumentar a qualidade das respostas".

${ }^{12}$ Entre os ministros e ministras que estavam no exercício de sua função durante a realização da pesquisa, quatro se recusaram, apesar das inúmeras tentativas, a conceder entrevistas: Celso de Mello, Joaquim Barbosa, Cármen Lúcia Antunes Rocha e Rosa Weber. Entre os ministros aposentados, Ellen Gracie nunca respondeu aos vários convites para participar. Nenhuma mulher foi então entrevistada nesta pesquisa.

${ }^{13}$ Mesmo os trabalhos que incluem entrevistas como fonte de informações em geral não seguem a estrutura narrativa e argumentativa usada neste artigo. A pesquisa de Kranenpohl é, aqui também, uma exceção. Além do livro já mencionado na nota 11, cf. também Kranenpohl (2009a, 2009b, 2009c).
} 
acima, é fazer uma tentativa de algo que poderia ser chamado de descrição interna. E, da mesma forma que as decisões do STF são o produto de onze opiniões distintas que, de algum modo, têm que se encaixar em um produto final, essa tentativa de descrição interna da prática deliberativa do STF também tenta construir a imagem de uma instituição a partir das opiniões individuais de seus membros. Com a diferença de que, no caso desta pesquisa, não são apenas onze os ministros que formam o panorama geral, mas dezessete. ${ }^{14}$

Contudo, apesar de ser um texto que procura em grande parte apresentar as opiniões dos ministros do Supremo Tribunal Federal sobre questões ligadas à deliberação no tribunal, isso não transforma o artigo em uma simples colagem de opiniões. De um lado, há uma sistematização dessas opiniões, classificando-as e salientando as concordâncias e divergências; de outro, por mais que não fosse objetivo da pesquisa tomar partido em relação aos temas debatidos, em alguns momentos foi necessário expor certas contradições presentes nos depoimentos ou ainda deixar explícitos eventuais problemas fáticos a eles ligados.

Uma última explicação sobre a pesquisa e as entrevistas é necessária: o objeto das conversas não era a atitude dos ministros em todas as dezenas de milhares de decisões anuais. $\mathrm{O}$ foco eram exclusivamente as decisões mais importantes, mais polêmicas, que chamam mais a atenção do público. Essa é uma explicação importante porque várias das afirmações sobre o papel do relator, sobre a quantidade de votos divergentes, sobre a dinâmica da deliberação, valem apenas para esses casos. Assim, para usar um exemplo relacionado ao papel do ministro relator, se é verdade que na grande maioria das decisões os demais ministros tendem a segui-lo sem grandes questionamentos, isso não necessariamente ocorre nas decisões mais relevantes, mais polêmicas e que chamam mais a atenção do público externo ao tribunal. Nessas, mesmo que o relator faça parte do grupo majoritário, isso não necessariamente significa que os demais ministros tenham concordado com seus argumentos. $\mathrm{O}$ mesmo vale para a prática de levar votos prontos para a sessão de julgamento; isso costuma acontecer apenas nas grandes decisões.

\footnotetext{
${ }^{14}$ Os ministros e ex-ministros entrevistados foram os seguintes: Ayres Britto, Carlos Velloso, Cezar Peluso, Dias Toffoli, Enrique Lewandowski, Eros Grau, Francisco Rezek, Gilmar Mendes, Ilmar Galvão, Luiz Fux, Marco Aurélio Mello, Moreira Alves, Nelson Jobim, Luís Roberto Barroso, Sepúlveda Pertence, Sydney Sanches e Teori Zavascki.
} 
Assim, uma pesquisa estritamente quantitativa poderia mostrar um cenário diferente daquele que serviu de pano de fundo para a minha pesquisa. No entanto, a escolha do foco parece-me mesmo assim justificada. Se o que se quer analisar é o papel do STF como corte constitucional, seu papel na relação entre os poderes, então não faz sentido investigar como os ministros se comportam nas decisões das dezenas de milhares de agravos, por exemplo. O que importa é a atitude dos ministros nas decisões que fazem parte do cotidiano de todos os tribunais constitucionais, como aquelas sobre reforma política, financiamento partidário, aborto, pesquisa em célulastronco, casamento de pessoas do mesmo sexo, ações afirmativas, drogas, entre outras. ${ }^{15}$

\section{Um conceito de deliberação}

Ao longo de todo este artigo, e de todos os artigos já publicados com resultados da mesma pesquisa, ${ }^{16}$ o conceito de deliberação ocupa um papel central. No entanto, não há um consenso sobre o que deliberação significa em geral e em um tribunal como o STF em especial. Mais do que isso, não há nem mesmo consenso sobre a ideia de que o STF - e tribunais equivalentes em outros países - deve ser um órgão deliberativo.

A pesquisa que embasa este artigo parte do pressuposto de que tribunais constitucionais e supremas cortes que exercem controle judicial de constitucionalidade devem ser órgãos deliberativos e, mais do que isso, baseados em um tipo muito específico de deliberação. São várias as razões que subsidiam essa tese, que já expus em detalhes em outro lugar (SILVA, 2013). Neste artigo, essas razões são um pressuposto, não algo a ser demonstrado ou defendido.

Como não há um conceito único de deliberação, e essa palavra poderia ser compreendida de formas distintas por cada um dos ministros, ao início de cada entrevista era fornecido o conceito de deliberação que deveria servir de base para a conversa. Trata-se de um conceito minimalista - que pode conviver com diferentes concepções mais exigentes de deliberação - definido nos seguintes termos:

Deliberação é a troca de argumentos, no interior de um corpo colegiado, com fins de persuasão e tomada de uma determinada decisão.

\footnotetext{
${ }^{15}$ Essa distinção entre casos relevantes e casos corriqueiros, pressuposta em todas as entrevistas, não é consensual, especialmente porque não há critérios estritamente objetivos para embasá-la. Eu já tive a oportunidade de defender essa distinção em outro lugar (cf. SILVA, 2016, p. 665-666). Não é possível repetir aqui todos os argumentos utilizados. Mas duas informações são importantes: (1) essa distinção não guarda relação com o tipo de ação ou o órgão julgador; e (2) ao início das entrevistas, embora não fosse oferecido um critério inequívoco para diferenciar caso relevante de caso corriqueiro, exemplos de casos considerados relevantes foram fornecidos aos ministros (Ellwanger, anencefalia, união de pessoas do mesmo sexo, Raposa Serra do Sol, pesquisa em células-tronco).
}

${ }^{16}$ Cf. nota 4 . 
O cerne do conceito, portanto, é a "troca de argumentos". É importante ressaltar e isso foi ressaltado aos ministros - que "troca de argumentos" não é sinônimo de mera "exposição de argumentos". Ou seja, um tribunal no qual eventuais argumentos aduzidos para justificar um voto têm como único objetivo satisfazer uma exigência formal de fundamentação, e não se destinam, portanto, a fomentar um debate, não é órgão deliberativo no sentido aqui apontado.

Um importante complemento ao conceito de deliberação - também salientado no início das entrevistas - é a ideia de colegialidade. ${ }^{17}$ Colegialidade não deve ser entendida como amizade ou impossibilidade de dissenso entre os ministros, mas como

disposição para trabalhar em equipe, ouvir os argumentos dos colegas e estar aberto a ser convencido por eles e, quando possível, tentar falar como grupo e não como indivíduo.

Essa definição, fornecida aos ministros, qualifica a "troca de argumentos". A troca de argumentos deve ser real, não simulada. É com base nesses conceitos de deliberação e colegialidade que as respostas dos ministros transcritas neste artigo e as conclusões tiradas com base nelas devem ser compreendidas.

\section{Deliberação e legitimidade do tribunal}

O debate sobre a legitimidade do controle judicial de constitucionalidade é antigo. Sobretudo nos países cujas constituições não preveem explicitamente a competência do Judiciário para realizar esse controle, as divergências na literatura são profundas. Alguém poderia afirmar que, no Brasil, essa é uma discussão pouco relevante, já que foi a própria Constituição que escolheu atribuir essa tarefa ao Judiciário, especialmente ao STF. Se a Constituição assim o fez, então não há como negar a legitimidade dos tribunais para fazer controle de constitucionalidade. No entanto, essa visão é apenas parcialmente correta. Não há dúvidas de que o Judiciário está autorizado a fazer controle de constitucionalidade no Brasil. Ainda assim, a tensão entre a competência dos poderes políticos (Legislativo e Executivo) para fazer leis e definir políticas públicas e a competência do Judiciário para controlá-las pode ser maior ou menor não apenas em razão da área, do contexto e da extensão das decisões judiciais, mas também do tipo de argumento usado pelos magistrados e da forma como a decisão ocorre. Em outras palavras, há quem afirme que tribunais são mais legítimos quando suas decisões são mais bem argumentadas e seu processo decisório é distinto daquele usado em outros órgãos colegiados, como o Poder Legislativo.

\footnotetext{
${ }^{17}$ Essa ideia é analisada em detalhes em outro artigo desta série (cf. SILVA, 2017, p. 235-239). Cf. também Silva (2013, p. 562-563).
} 
De forma geral, embora essa relação entre qualidade da decisão e legitimidade do controle judicial de constitucionalidade não parecesse evidente aos ministros, ao serem confrontados com a pergunta, todos indicaram haver essa relação:

Quanto mais convincente for o pensamento do tribunal, maior será a legitimidade da decisão. (ministro C)

A legitimidade do Executivo é dada pelo voto, a legitimidade do Legislativo é dada pelo voto popular também, a legitimidade do Judiciário é dada pela fundamentação, pela razão. (ministro F)

Eu acho que a legitimidade no nosso sistema não tem outra forma de se acentuar senão pela qualidade do julgamento. (ministro D)

Quanto mais solidamente fundamentada uma decisão, mais legítima. (ministro $\mathrm{H}$ )

Quando indagados de forma geral se o processo deliberativo e decisório do STF fomenta boas decisões, poucos foram os ministros que expressaram uma posição clara a respeito. $\mathrm{O}$ ministro $\mathrm{B}$ rejeitou haver ligação entre forma de deliberar e qualidade das decisões. Embora concordasse que a legitimidade do tribunal é fomentada pela qualidade de suas decisões, afirmou:

Não acredito que isso [modo de deliberação] seja determinante [para a qualidade das decisões]. (ministro B)

Já o ministro E, embora tenha expressado certo ceticismo em relação à possibilidade de classificar, de forma objetiva, decisões como boas ou ruins, não deixou de ver uma relação entre o processo decisório e a legitimidade do tribunal:

Eu acho que falar de qualidade das decisões é utilizar uma categoria extremamente subjetiva, mas eu acho que a transparência da deliberação permite a legitimação discursiva do tribunal, permite que haja um controle social sobre a qualidade do argumento, sobre a racionalidade do argumento. (ministro E)

O ministro R, por sua vez, foi enfático em afirmar que a prática do STF não fomenta bons debates e boas decisões:

Não, não fomenta. Ao contrário, porque [...] estimula a divergência. (ministro R)

Apenas quando indagados se, nas decisões dos casos mais importantes, o tempo de leitura de votos e o tamanho final das decisões (que em alguns casos têm centenas de páginas) poderiam afetar a qualidade da decisão, os ministros expressaram uma opinião mais clara. Com variações de intensidade, quase todos encaram a tendência a produzir decisões muito longas como algo que compromete a consistência decisória do tribunal: 
Há um mau hábito de achar que escrever muito significa ser mais consistente. (ministro C)

Eu acho que as deliberações deveriam ser mais sucintas, a votação mais sucinta, as publicações mais sucintas. (ministro $G$ )

Um jovem advogado se perde lá. Ele fica inteiramente desorientado. Se ele for buscar a base da argumentação que justificou o voto, muitas vezes ele vai verificar que aquilo que o ministro falou não tem nada a ver com o voto que ele deu. (ministro T)

A minha maior crítica adversa aos colegas [...] tinha a ver com o método de trabalho, com excesso de tinta no papel e excesso de palavras ao microfone da sessão. Sempre observei isso. Há ministros que escrevem 85 páginas pra dizer o que eu digo em 4 páginas, há ministros que falam 60 minutos para dizer o que pode ser dito tranquilamente em 6 minutos. (ministro Q)

Eu não tenho dúvida nenhuma de que não há matéria [que justifique] essas decisões de seiscentas páginas, quinhentas páginas. (ministro U)

Embora não fosse o foco da pergunta, alguns ministros também enfatizaram que a extensão das decisões e a fragmentação argumentativa a ela relacionada tendem a gerar um descompasso entre o que diz a ementa e o que os ministros argumentaram ao longo de seus votos.

Eu sou a favor [...] de que, ao final da votação, o relator para o acórdão produza uma ementa na qual fique explicitado qual foi a tese jurídica do acórdão, [...] e esta ementa deve ser aprovada pela maioria que se formou. [...] Eu acho que um dos problemas dos casos mais difíceis é a dificuldade de saber exatamente o que foi decidido e acho que, para superar este problema, a ementa - que, na minha experiência, é o que é a maior parte das pessoas leem - deve traduzir a tese jurídica vencedora e deve ser aprovada a posteriori. (ministro $\mathrm{E}$ )

[A extensão dos votos e das decisões] compromete a qualidade porque você não sabe do que se trata. E tem um problema grave que é a ementa. Se pegar uma ementa do Celso de Mello, é um acórdão novo, aquele troço comprido. (ministro R)

Apenas um ministro apontou alguma vantagem em votos mais longos:

O ideal seria que se fizesse realmente um acórdão sintetizando os pontos de vista. A opinião da corte. Isso é o ideal. A vantagem de fazer votos longos é que às vezes se chega a um resultado por caminho diferente, então ali estão expostos todos os caminhos. (ministro D) 
Por fim, um dos ministros, embora crítico em relação ao aumento do tamanho das decisões, mostrou-se otimista em relação ao futuro:

Nós vamos ter que fazer votos mais curtos e vamos cada vez mais substituir a leitura pela oralidade dos votos. Como nós sabemos que um grande público nos acompanha, e como sabemos também que você chama muito mais a atenção dos outros ministros quando você oraliza o voto, e não quando lê, então no futuro nós vamos ter votos muito mais oralizados do que lidos, e muito mais curtos do que longos. [...] Vai chegar um momento em que o Judiciário fará da síntese, da brevidade, um pilar do seu funcionamento. Assim como nós já estamos fugindo do "juridiquês" e usando uma linguagem mais palatável para o grande público. É uma fonte de legitimidade. A linguagem palatável e acessível é uma fonte de legitimidade. (ministro $\mathrm{H}$ )

\section{A definição da pauta: centralização e impactos na deliberação}

Durante muito tempo, a definição da pauta de julgamentos do STF foi encarada como uma tarefa meramente administrativa, e a literatura constitucional pouco ou nada se interessava pela questão. É possível até mesmo afirmar que, até a gestão do ministro Nelson Jobim na presidência do tribunal (2004-2006), o STF não tinha propriamente uma pauta de julgamentos. Todos os processos liberados pelas relatorias poderiam ser julgados a qualquer momento, sem aviso prévio. A partir da criação de uma pauta, ficou claro que o poder de definir o que vai ser julgado, e em que momento, é sem dúvida um dos mais importantes dentro do tribunal. Não por acaso, nos últimos anos tem crescido rapidamente o número de estudos sobre a questão (cf., por exemplo, ARGUELHES; HARTMANN, 2017; ESTEVES, 2020; FALCÃO; OLIVEIRA, 2013).

A definição da pauta de julgamentos de um tribunal é uma questão de poder em dois sentidos. Poder interno, porque integrantes de um tribunal podem ter - e no STF certamente têm - capacidades distintas para influenciar a composição da pauta. ${ }^{18} \mathrm{E}$ poder externo, porque o STF julga quando quer os processos que interessam a agentes externos, sejam os outros poderes (Legislativo e Executivo), sejam agentes não estatais. Neste tópico, e nesta pesquisa, o que interessava não era investigar esses poderes em si mesmos, mas o impacto que a definição da pauta pode ter na deliberação e na dinâmica

\footnotetext{
${ }^{18}$ No STF, todos os integrantes influenciam, de alguma maneira, essa composição. Quem define o que entrará na pauta é a presidência. Mas, para que um processo entre na pauta, é necessário que o relator ou relatora o tenha liberado. Por fim, qualquer ministro ou ministra pode interromper um julgamento por meio de um pedido de vista e, dessa forma, retirar o processo da pauta. Embora todos possam influenciar a composição da pauta, a extensão do poder de cada um é distinta.
} 
do processo decisório. O tema central nesse âmbito, portanto, é bem menos polêmico do que o exercício do poder de definir as prioridades de um tribunal e está relacionado simplesmente a uma questão de preparo para a deliberação. Em outras palavras, o cerne do debate é a antecedência na definição e divulgação da pauta.

Sobre essa questão, há uma certa diferença de percepção entre antigos ministros e ministros na ativa. Embora não componham dois campos homogêneos, a tendência observada foi a de que antigos ministros em geral não veem grandes problemas na divulgação da pauta de julgamentos com menos de uma semana de antecedência, como ocorria naquele momento:

Eu nunca ouvi no passado queixa sobre isso. Hoje ouço! (ministro Q)

São, são sim. Eu acho que são divulgadas com a devida antecedência. (ministro O)

Não parece ser difícil explicar por que antigos ministros tendem a ver menos problemas com o momento em que a pauta é definida e comunicada pela presidência aos demais ministros e ministras. Como muitos deles entraram no tribunal em uma época em que não havia divulgação de pauta com antecedência, ter a oportunidade de saber na semana anterior o que será julgado na semana corrente parece ser quase um luxo. A resposta do ministro $\mathrm{N}$ resume bem essa sensação:

É suficiente, porque parece que é na quinta-feira que se publica. (ministro $\mathrm{N}$ )

A iniciativa do ministro Nelson Jobim de, em sua gestão como presidente, racionalizar e publicizar a pauta com alguma antecedência foi reconhecida de pronto por vários ministros:

Aqui é preciso fazer um registro histórico. Até a presidência do ministro Nelson Jobim não havia a divulgação das pautas. [...] Se avançou alguma coisa? Do ministro Jobim pra cá, não, continua o mesmo sistema, ou seja, a pauta é lançada na internet na quinta-feira por volta de dez, onze horas da noite. (ministro F)

Isso veio na gestão Jobim e o intuito foi o de organizar a pauta, porque se sabia em geral com uma antecedência mínima o que seria julgado. (ministro B)

Entre os ministros na ativa, todos entendem que a pauta deveria ser definida com maior antecedência e que, do jeito que hoje ocorre, não há tempo suficiente para se preparar para o debate: 
Não, não há tempo, praticamente não há tempo [para se preparar]. A não ser que seja um caso muito momentoso. Mas, no dia a dia, não há tempo para nós nos prepararmos quanto a certas matérias. (ministro A)

Deveríamos fazer com mais tempo. (ministro $\mathrm{H}$ )

A gente não tem segurança do que vai ser julgado, isso continua a ser uma incógnita. (ministro B)

Eu acho que o sistema é muito ruim. (ministro E)

O ideal seria [...] que se fizesse uma pauta semestral ou algo assim. (ministro D)

A relação entre antecedência na divulgação da pauta, tempo disponível para se preparar e dinâmica da deliberação pode não ser evidente. Um fator chave para compreendê-la é a assimetria de informações que a divisão do trabalho em um tribunal tende a gerar. No STF, essa assimetria opõe o relator - que em geral tem mais conhecimento acerca do caso sob sua relatoria - aos demais ministros, que tendem a ter menos informações. Por isso, quanto menor a antecedência na divulgação da pauta, maior tenderá a ser essa assimetria de informações. No passado, a falta de tempo hábil para se preparar para uma sessão de julgamento no STF muitas vezes fomentava uma das seguinte situações, ambas prejudiciais à ideia de deliberação como troca de argumentos: um ministro (muitas vezes o primeiro a votar após o relator) ou pedia vista e interrompia a deliberação ou aderia à tese do relator, não necessariamente porque concordava com ela, mas porque não tinha condições de oferecer contra-argumentos bem informados. ${ }^{19}$ Essa consequência da falta de tempo para se preparar foi enfatizada pelo ministro B. Ao se referir à época em que o STF não tinha uma pauta propriamente dita, o ministro salientou o impacto que a falta de tempo para se preparar costumava ter nos ministros com menos tempo de tribunal, que são os primeiros a votar:

Os colegas recém-chegados no tribunal [muitas vezes] ou tinham que pedir vista ou tinham que seguir o relator. Em suma, tinham uma enorme dificuldade. (ministro B)

\footnotetext{
${ }^{19}$ Não se deve perder de vista que, no STF, nem mesmo o voto do ministro relator é distribuído com antecedência. As consequências desse fato seriam um pouco mitigadas se os ministros relatores se sentissem obrigados, por regra regimental ou costume, a fazer um voto que exponha todas as informações relevantes e todos os caminhos possíveis para a decisão do caso, como ocorre em tribunais de alguns países. No STF, no entanto, o ministro relator não compartilha todas as informações e argumentos de que dispõe, apenas aqueles que subsidiam o caminho que ele escolheu. O relator, portanto, não desempenha um papel informador; ele defende firmemente uma única tese (cf. SILVA, 2015a).
} 
A despeito da tendência mencionada anteriormente, segundo a qual os ministros aposentados tendem a ver menos problemas na divulgação da pauta com menos de uma semana de antecedência, alguns deles também se mostraram críticos:

Eu acho que mais tempo seria mais adequado. (ministro $\mathrm{P}$ )

[A pauta] deveria ser divulgada com maior antecedência. Como ela tem uma quantidade imensa de processos, [...] não dá para se preparar com antecedência. (ministro T)

Segundo alguns ministros, ainda mais problemático do que a pouca antecedência na divulgação é o fato de que a pauta, mesmo depois de divulgada, ainda pode ser modificada livremente pelo presidente do tribunal:

[As pautas não são divulgadas com a devida antecedência] e, pior ainda, elas mudam às vezes menos de 24 horas antes [da sessão]. Às vezes eu tenho uma pauta que eu estudei de noite e chego de manhã antes da sessão e [me dizem]: "ministro, caíram tais, tais e tais processos"... Eu me dediquei a noite inteira para estudar um processo e entra outro no lugar. Isso é errado, isso é ruim. (ministro I)

O que está acontecendo é que a colocação em pauta não está significando nada. (ministro Q)

Embora o que estava em discussão era tão somente o impacto da pauta no processo deliberativo, alguns ministros fizeram críticas mais amplas à própria forma como a pauta é definida:

Eu diria que ela está ao arbítrio do presidente. Ele decide o que vai entrar e o que não vai entrar. A pauta tinha que ter uma lógica, tinha que ter um consenso. Deveria ter uma certa estabilidade e não tem. (ministro I)

Eu penso que a maneira como a pauta é feita hoje não é democrática. Ela não é discutida coletivamente com os ministros. Isso tem uma razão de ser: todo mundo ou foi ou vai ser um dia presidente. Então ninguém questiona o fato do presidente monopolizar a pauta, porque um dia ele vai ter esse monopólio de poder. [...] O maior poder que um tribunal pode ter é a sua pauta. (ministro F)

Além do poder de agenda do presidente do tribunal, alguns ministros, ao tratarem do papel do relator no processo deliberativo, também ressaltaram o controle do tempo como um importante poder (cf. SILVA, 2015a): 
O relator administra a tese que ele tem sob julgamento com o tempo. Se ele for uma pessoa de visão tática, aí é uma questão não estritamente técnico-jurídica, mas que faz parte da formação do ser humano e também de quem chegou à Suprema Corte, de saber o seguinte: "olha esse não é o momento de eu levar tal tema”. [...] Eu, por exemplo, eu não me surpreendi que o ministro Marco Aurélio não tenha trazido a anencefalia antes da aposentadoria do ministro Eros Grau. (ministro F)

$\mathrm{O}$ relator tem um papel quase absoluto quanto à agenda, porque o processo só vai a julgamento a partir do momento em que ele resolva levar o processo a julgamento. [...] Esse é um poder grande de supressão da discussão (ministro E)

\section{Princípios e métodos de interpretação constitucional}

Durante as décadas de 1990 e 2000, entre os principais temas da produção da literatura constitucional brasileira estavam os princípios e os métodos de interpretação constitucional. Em certa medida, no entanto, o debate sobre esse tema ocorria sem qualquer conexão com a prática interpretativa e decisória do Supremo Tribunal Federal. Debatiam-se métodos em abstrato, sem grande preocupação com sua aplicação ou aplicabilidade (cf. SILVA, 2005). Com exceção da proporcionalidade, que alguns ministros mencionam em algumas decisões, como regra geral os ministros e ministras do STF não explicitam os métodos de interpretação usados para chegar a determinada conclusão. Ainda assim, é possível supor que cada um tenha sua própria maneira de encarar a tarefa interpretativa.

A relação entre métodos de interpretação constitucional e deliberação não é evidente. O que se pretendia indagar era sobretudo se a total autonomia de cada ministro para definir seus princípios e métodos interpretativos não poderia ser um empecilho adicional ao debate, já que cada um poderia estar "falando uma língua distinta”.

Poucos foram os ministros que identificaram um problema nesse sentido, como os ministros I, T e B:

Uma das grandes razões do desentendimento entre os ministros é justamente que eles partem de metodologias interpretativas distintas. (ministro I) 
Esse diálogo efetivamente acaba não existindo. (ministro T)

Isso é um debate doutrinário muito amplo e cada ministro tem um referencial teórico. Então é difícil. (ministro B)

Alguns ministros, embora reconheçam que a produção de votos individuais pode dar ensejo a decisões que sejam a soma de caminhos interpretativos com pontos de partida metodológicos distintos, não avaliam essa possibilidade como um problema, sobretudo porque ela não vale apenas para questões metodológicas, mas para qualquer questão:

Eu acredito que [...] a essência do colegiado está no somatório de forças e na complementação. Nós nos complementamos mutuamente. [...] Um colega traz um dado, o outro faz uma ponderação, apresenta um novo enfoque, e se chega ao resultado, que é o resultado democrático, considerada a maioria. Isso [..] é inerente ao fato de termos várias cabeças no colegiado. (ministro A)

Os demais ministros não atribuem uma função aos métodos de interpretação como guias do processo decisório. Alguns deles claramente afirmam que os métodos não fazem parte do seu cotidiano:

Eu não acho que a metodologia seja um componente decisivo de nenhum magistrado. A metodologia é mais uma justificação da solução que se considerou justa do que qualquer outra coisa. Numa boa quantidade de casos, o primeiro julgamento que o juiz faz é qual é a solução justa. [...] Depois se buscam os fundamentos legitimadores. (ministro E)

Não há [...] uma preocupação em se deixar levar por uma metodologia clara. Eu acho que isso não existe. (ministro C)

Eu acho que o método não é um percalço, não é uma pedra no caminho, porque nenhum ministro fala do método que adotou pra chegar. (ministro $\mathrm{H}$ )

Outros, embora identifiquem um certo discurso sobre métodos e princípios de interpretação constitucional no STF, tendem a encarar esse discurso com grande desconfiança:

Um problema muito sério é a banalização de certas palavras, como um "abra-te sésamo". Por exemplo, a palavra "proporcionalidade". Outro chavão é a "dignidade da pessoa humana”. Terrível! Eu acho que há uma banalização. (ministro D) 
[...] o princípio da proporcionalidade justifica qualquer tipo de discussão, qualquer tipo de decisão. (ministro T)

Toda vez que aparecia um princípio eu anotava, porque aparecia princípio para tudo que era gosto. [Há até um] Dicionário de Princípios Jurídicos. Está tão difícil que está precisando de dicionário... Alguma coisa está errada aí! (ministro R)

\section{O processo decisório e a possibilidade de precedentes vinculantes}

Não há consenso no Brasil sobre o que significa vinculação a precedentes. Embora não haja dúvidas de que uma decisão pela inconstitucionalidade de uma lei, tomada pelo STF no exercício do controle abstrato, concentrado e principal, impede que outros tribunais continuem a aplicá-la, não é claro se os efeitos vinculantes previstos pela Constituição e pela legislação ${ }^{20}$ devem ir além da dicotomia constitucional/inconstitucional e abarcar também os argumentos e fundamentos da decisão. E, se devem ir além, imediatamente surge a questão: como identificar quais são os argumentos e fundamentos vinculantes? Essa pergunta é legítima em razão do processo decisório do tipo seriatim, adotado pelo STF, no qual não há propriamente uma opinião da corte, com uma fundamentação decisória única, mas tão somente votos individuais, com argumentos e fundamentos individuais.

Indagados acerca da possibilidade de construção de um sistema de precedentes vinculantes no STF, quase todos os ministros narraram haver uma grande dificuldade nesse âmbito:

Eu diria que [a forma de decisão] torna extremamente difícil a construção de um sistema de precedentes, porque nem sempre é claro o que exatamente foi decidido. (ministro E)

Há muita gente que, embora esteja no tribunal há muito tempo, ainda não domina essa coisa, acha que ele escreve a ementa com os fundamentos que ele eventualmente colocou no seu voto. Isso não traduz obviamente [o inteiro teor da decisão]. (ministro B)

\footnotetext{
${ }^{20}$ Constituição, art. 102, $\$ 2^{\circ}$ : "As decisões definitivas de mérito, proferidas pelo Supremo Tribunal Federal, nas ações diretas de inconstitucionalidade e nas ações declaratórias de constitucionalidade produzirão eficácia contra todos e efeito vinculante, relativamente aos demais órgãos do Poder Judiciário e à administração pública direta e indireta, nas esferas federal, estadual e municipal"; Lei 9.868/1999, art. 28, parágrafo único: "A declaração de constitucionalidade ou de inconstitucionalidade, inclusive a interpretação conforme a Constituição e a declaração parcial de inconstitucionalidade sem redução de texto, têm eficácia contra todos e efeito vinculante em relação aos órgãos do Poder Judiciário e à Administração Pública federal, estadual e municipal”.
} 
Às vezes nós podemos ter onze razões diferentes. É por isso que eu digo que é difícil formar um sistema [de precedentes], como seria o ideal. Isso facilitaria para dar vinculação não apenas às conclusões, mas aos fundamentos, que no fundo são o mais importante. (ministro D)

Por causa da retórica fica tudo muito difícil... aí surge aquela discussão se aquilo é um precedente ou um obter dictum. Entra naquele negócio interminável "não, mas isso daí não foi uma decisão, isso daí foi um obter dictum do fulano que foi para ementa, mas a ementa não foi uma decisão", aí embola tudo. (ministro R)

O sistema de precedentes passa a ser extremamente dúbio, frágil. (ministro T)

Pouquíssimos ministros externaram visão distinta. O ministro $G$, porque entende que apenas a conclusão da decisão, e não seus fundamentos, vincula:

No sistema brasileiro, a gente leva em consideração a conclusão. [...] O que vai firmar o precedente é a conclusão do voto. (ministro G)

E o ministro I, para o qual o STF não deve levar tão a sério seus precedentes, porque "cada caso é um caso":

Eu, cada vez mais, me convenço de que cada caso é um caso. Tirando os casos de matéria tributária, criminal, que são aqueles casos rotineiros, eu acho que cada caso é um caso e não dá pra se fiar em precedentes. (ministro I)

\section{Audiências públicas: inovação, formalismo e pouca participação}

Os dois últimos blocos de perguntas das entrevistas diziam respeito à relação do STF com pessoas e instituições que não fazem parte do tribunal e tampouco são participantes formais dos processos. De um lado, o objetivo era indagar se e como as audiências públicas, que passaram a fazer parte do cotidiano do tribunal em 2007, produziam efeitos nas deliberações. De outro lado, era investigar se os ministros, ao participar das deliberações e tomar suas decisões, levavam em consideração como seus argumentos seriam recepcionados pelo público externo ao tribunal (sejam os poderes políticos, seja a sociedade civil, especialmente a academia). O primeiro aspecto (audiências públicas) será abordado neste tópico; o segundo, no tópico seguinte. 
Em relação às audiências públicas, foi possível identificar uma divisão, ainda que não absoluta, entre ministros na ativa e ministros aposentados. Os primeiros expressaram uma opinião muito mais favorável às audiências públicas e aos seus efeitos no processo decisório do tribunal do que os segundos:

Tem [impacto no processo decisório]. Primeiro, o ministro só convoca audiência pública quando ele sente que aquele tema requer uma expertise para além do conhecimento jurídico. A audiência pública é outro ingrediente de legitimação das decisões na medida em que significa uma homenagem ao pluralismo. (ministro $\mathrm{H}$ )

Eu tenho a impressão de que ela está cumprindo um papel de informação. Obrigou o relator a dialogar com essas outras realidades e abordagens, então acho que nesse sentido é uma melhora significativa. (ministro B)

É fundamental, porque esse suposto conhecimento enciclopédico do juiz é uma blasfêmia. Não existe isso de você saber tudo de tudo. E, por outro lado, a audiência pública dá também uma visão da repercussão social da decisão. (ministro G)

Tem [impacto] na elucidação da matéria. Eu me refiro, por exemplo, à audiência pública no caso da anencefalia. [Foram] quatro ou cinco sessões e o que coligimos de material foi algo impressionante, com enfoques dos diversos segmentos: acadêmico, técnico, religioso. E eu penso que nós julgamos a partir de fatos, a partir de elementos, a partir de esclarecimentos. (ministro A)

As audiências públicas curiosamente repercutem sobre os ministros não pela audiência, mas via imprensa. Os ministros geralmente não participam das audiências e nem sempre se produz um relatório, que seria uma possibilidade para quem não participou acompanhar. Mas a repercussão dos argumentos ou na imprensa ou em artigos específicos pode afetar o julgamento. Eu acho que ela tem essa conotação positiva de deixar organismos da sociedade se manifestar. (ministro E)

Embora a pergunta relacionada às audiências públicas também demandasse algum exemplo concreto de como as audiências afetam a deliberação e a tomada de decisão, é possível perceber que as respostas tenderam a fazer um balanço positivo da ideia, não necessariamente da prática. A forma como as audiências têm sido realizadas foi objeto de inúmeras críticas. Como afirmado acima, especialmente dos ministros aposentados, mas também de ministros na ativa. $\mathrm{O}$ ministro I, por exemplo, segundo o qual as audiências são importantes "porque você traz o povo para dentro da corte; 
[são] um mecanismo de fortalecer a democracia participativa e de legitimar as decisões [do tribunal]", também ressaltou que:

os ministros não têm comparecido às sessões, então limita muito. Com relação tanto àquele que organiza a audiência pública quanto àquele que está na audiência pública, eu tenho a impressão de que todos temos uma cabeça feita já. Eu já sabia o que eu ia decidir [em determinado caso]. É possível que em casos extremos alguém mude de ideia, mas eu não acredito. (ministro I)

As maiores críticas em relação à prática das audiências públicas foram direcionadas à dinâmica dos trabalhos, à participação de juristas em um ambiente que, segundo uma determinada concepção, deveria ser destinado a esclarecer os ministros e ministras sobre questões técnicas não jurídicas, ${ }^{21}$ e ao fato de que os ministros e ministras simplesmente não comparecem às audiências:

A audiência pública é realizada [...] na forma de sustentação oral. O sentido de audiência pública na cultura binária jurídica brasileira tem que ser modificado. Não é vir alguém à tribuna sustentar a sua posição por dez, quinze, vinte minutos e ir embora, aí vem outro [e faz o mesmo]. No dia em que eu chamar uma audiência pública, [...] eu vou colocar "eu quero ficar ouvindo vocês por três horas, um pegando o outro". Vamos ver "você fala que a vida acaba em tal lugar, você fala que vida acaba aqui...”. Vamos ouvir o debate. Deixa ali solto, sem formalismo, sem formalismo. (ministro F)

A audiência pública [é] uma sessão de defesa de posições divergentes por parte de pessoas da área do direito. Eu acho que o bom da audiência pública [seria] ouvir pessoas ligadas ao caso [...], mas que não sejam propriamente [...] juristas. Isso é importante, porque a visão jurídica tende a transformar a audiência pública num prévio debate do que está acontecendo dentro do processo. Uma reprodução do que está no processo. Aí não tem muito sentido prático. (ministro D)

Essas audiências públicas começaram a ficar mais ou menos parecidas com as CPIs do Congresso. [Coloca-se] em sessão pública questão de

\footnotetext{
${ }^{21} \mathrm{O}$ art. $9^{\circ}, \$ 1^{\circ}$, da Lei 9.868/1999, tem a seguinte redação: "Em caso de necessidade de esclarecimento de matéria ou circunstância de fato ou de notória insuficiência das informações existentes nos autos, poderá o relator requisitar informações adicionais, designar perito ou comissão de peritos para que emita parecer sobre a questão, ou fixar data para, em audiência pública, ouvir depoimentos de pessoas com experiência e autoridade na matéria”. É possível pressupor que a primeira parte do dispositivo relacionada à requisição de informações e à designação de peritos para emitir parecer - claramente faz referência a questões e pessoas de fora do âmbito jurídico. Já a segunda parte, específica sobre audiências públicas, é mais genérica ("ouvir depoimentos de pessoas com experiência e autoridade na matéria”). Ainda assim, os ministros críticos à participação de juristas em audiências públicas parecem pressupor que só faz sentido convocar pessoas com "experiência e autoridade" em matérias não jurídicas, já que os próprios ministros e ministras do STF seriam as pessoas com "experiência e autoridade" na área jurídica.
} 
direito. As audiências públicas estão se transformando [em] um debate sobre a questão de direito na frente do tribunal. Mas isso é coisa para o advogado fazer. (ministro $\mathrm{R}$ )

Eu não concebo que possa se tirar alguma conclusão de uma audiência pública. Quem vai julgar com base no direito posto, eu acho difícil. (ministro $\mathrm{N}$ )

Como mencionado, o fato de os ministros não irem às audiências foi objeto de crítica recorrente:

Alguns ministros desprezam solenemente, olimpicamente, o produto das audiências públicas. Alguns têm uma tendência a achar que aquilo é vedetismo do ministro que convocou. Você vê que não está havendo dentro do tribunal um sentimento coletivo de prestígio às audiências públicas. Isso me parece uma lástima, porque nas audiências públicas ouve-se muita tolice, mas ouve-se também muita coisa sensata, e é possível distinguir uma das outras. (ministro Q)

[Os ministros] nem vão, nem querem saber disso. Graças a Deus que no meu tempo não se cogitou fazer [audiências públicas]... (ministro N)

Acho que em certos temas é razoável e é produtiva, mas a experiência mostra uma grande dificuldade de levar mais do que o relator à audiência pública. (ministro $\mathrm{P}$ )

As críticas não são apenas aos outros (como frequentemente ocorreu ao longo das entrevistas). Os ministros não pareciam ter dificuldade em reconhecer que não vão às audiências:

Olha eu não participei de nenhuma das audiências públicas. Eu não sou capaz de responder pelos ministros que participaram. (ministro C)

Entre os críticos, provavelmente o mais direto e incisivo foi o ministro T. Ao ser indagado se as audiências têm algum efeito no processo deliberativo e decisório do STF, ele respondeu:

Nenhum, nenhum, nenhum, nenhum. É um teatro! (ministro T) 


\section{O STF e seu público}

Como mencionado no início deste artigo, as entrevistas da pesquisa foram realizadas entre setembro de 2011 e agosto de 2013. Praticamente todas elas, portanto, ocorreram antes das manifestações de junho de 2013, antes de a operação Lava Jato vir à tona, antes do impeachment de Dilma Rousseff e, sobretudo, antes da extrema polarização que passou a ser a tônica do debate político brasileiro desde então. Essa polarização, como se sabe, envolve, entre inúmeras outras coisas, uma enorme pressão sobre o STF. As críticas à instituição e aos ministros têm sido em muitos casos violentas.

Diante dessa mudança de contexto, é possível que o último tema das entrevistas - a relação do tribunal com o público externo - tenha sido aquele cujas respostas mais sofreram com a passagem do tempo entre o momento das entrevistas e a publicação deste artigo. Os ministros foram questionados se, ao participar das deliberações e ao redigir seus votos, pensavam apenas na decisão do caso ou também no impacto que a decisão poderia ter em outros âmbitos e na forma como o público externo receberia a decisão. Na época, uma parcela importante do que se queria dizer com público externo era a academia. Atualmente, as principais reações às decisões do STF são aquelas que ocorrem nas redes sociais. Embora as principais plataformas de redes sociais - Facebook e Twitter, por exemplo - já existissem na época, elas ainda não tinham a importância que têm hoje e, sobretudo, as decisões do STF não eram um tema tão relevante nesses fóruns como são hoje.

Por isso, as redes sociais estão ausentes nas respostas expostas neste tópico.

Poucos foram os ministros que afirmaram não pensar em mais nada além do caso em si:

Não, eu pensava na decisão do caso. No meu entendimento, juiz deve decidir o caso e não ficar dependendo de opiniões estranhas ao julgamento. (ministro U)

Eu penso em primeiro lugar no meu dever de coerência. (ministro E)

Você primeiro constrói uma decisão justa e depois você dá a ela uma roupagem jurídica. Nós debatemos a juridicidade da solução, a repercussão da solução sem nos deixarmos pautar pela opinião pública, mas dando legitimação àquela solução. (ministro $G$ )

A academia, usada apenas como um dos exemplos de público externo, foi uma constante nas respostas, especialmente daqueles ministros que também são acadêmicos e dão aulas em universidades: 
Quando você é acadêmico, [...] é inevitável. Você diz "epa, tenho que refinar, requintar, tenho que ver". Eu até diria que não deveria, mas é impossível. E no mundo político eu acho que também [penso]. Não é que [...] instâncias não jurisdicionais lhe inibam, não é isso. Mas você pensa sim. Você sempre se pega avaliando o impacto político, social, religioso, acadêmico das suas decisões. [Um ministro] não pode jogar para a plateia, mas ele não pode ignorar a plateia, porque faz parte dessa plateia o jurisdicionado, no mínimo. (ministro $\mathrm{H}$ )

Eu tenho uma preocupação de que [a decisão] seja objeto de uma crítica acadêmica. Eu penso nisso também. Ainda que não se faça hoje, mas depois alguém vai fazer história a respeito, vai pensar, vai comparar o que foi dito, o que poderia ter sido explorado mais vezes ou menos vezes. Eu penso nisso sim. (ministro C)

Ah, pensava. Não em todos [os casos], porque nem todos têm essa relevância. Mas nos casos importantes, eu pensava como isso iria ser encarado na academia, onde eu dava aula [...]. Como os meus alunos iriam receber isso, principalmente os de mestrado. [Também há a questão] da relação entre os poderes. Eu acho que um ministro do Supremo tem que cuidar disso. É claro que não é para alterar um convencimento, mas ele deve pensar, sim, nos possíveis estragos que a sua decisão pode causar em termos de harmonia entre os poderes. (ministro $\mathrm{O}$ )

Pensava, pensava [no público externo]. Com muita discrição, com muita parcimônia, mas pensava sim. Isso não era o determinante, mas isso era seriamente considerado em todos os seus aspectos. O que os meus alunos na universidade [...] pensarão da tomada desse caminho? (ministro Q)

Como mencionado anteriormente, poucos foram os ministros que afirmaram não pensar nas consequências supostamente não jurídicas de suas decisões ou na forma como o público externo, ao tribunal e ao caso que está sendo julgado, receberá essas decisões. É sempre difícil aferir o quão sinceras foram essas respostas. ${ }^{22}$ Mas o mais importante neste ponto é o outro lado da moeda: tendo em vista que a comunidade jurídica, por muito tempo e, em grande medida, até hoje, não costuma ver com bons olhos que argumentos considerados extrajurídicos influenciem as decisões judiciais, é possível pressupor que os ministros que assumiram que pensam em outros públicos, em outros âmbitos, em outros tipos de argumentos, muito provavelmente foram sinceros em suas respostas. E é importante notar que esses são a maioria no tribunal:

\footnotetext{
${ }^{22}$ Essa constatação vale, como já foi sublinhado no início deste artigo, para todas as respostas (cf. nota 7).
} 
No mundo acadêmico, não, sinceramente eu não penso. Agora, no que eu penso é no impacto que vai ter na sociedade e, sobretudo, na consequência que aquele caso concreto produz. (ministro D)

Eu penso no impacto que o meu voto vai ter nas relações entre os poderes, na economia do país, na vida social. Eu não estou muito preocupado [com a academia] não. O Celso [de Mello], homem respeitado, [pensa] "eu estou escrevendo os meus votos para o futuro, um dia os historiadores vão ler o meu voto..." Eu não estou preocupado. Eu dirijo os destinos do país neste momento, aqui e agora, então eu vejo qual é a repercussão dos meus votos na realidade concreta. Claro que eu procuro me esmerar, procuro fazer um voto juridicamente consistente, mas eu acho que nós somos um órgão de poder político. (ministro I)

Diziam que eu era consequencialista. Era a palavra que usavam. Eu pensava: onde é que vai bater isso? (ministro $\mathrm{R}$ )

Eu gostava de conhecer as consequências, de antever as consequências. Não de me guiar por elas, mas não ser indiferente a elas. (ministro S)

[Um ministro] tem que ter o peso da responsabilidade dos efeitos [das decisões]. (ministro F)

Como salientado na introdução deste tópico, as entrevistas foram conduzidas entre 2011 e 2013. Naquele momento, as redes sociais não tinham a importância que têm hoje e, ainda mais importante, o STF e seus ministros não eram temas de tanto destaque nessas plataformas. Desde então, o STF passou a ser objeto constante de discussões e críticas, muitas vezes violentas, nas redes sociais. Embora a preocupação com elas não esteja presente nas respostas, pela razão exposta acima, não parece haver dúvidas de que os ministros se preocupam com aquilo que pensam e escrevem os usuários dessas redes. Muitos ministros (e também ex-ministros) têm contas e são ativos em plataformas como Twitter e Instagram. ${ }^{23}$ Isso parece indicar uma disposição a produzir conteúdo para esse público. É certo que desse fato não se pode concluir que, ao escrever seus votos e participar dos debates, os ministros e ministras necessariamente pensem nesse público e se deixem influenciar por ele. Contudo, se na época da realização das entrevistas quase todos expressaram alguma preocupação com a recepção de seus votos e decisões pelo público externo, é plausível supor que, atualmente, esse público inclua também ao menos parte dos usuários de redes sociais. ${ }^{24}$

\footnotetext{
${ }^{23} \mathrm{Na}$ atual composição do tribunal, possuem conta em alguma plataforma de rede social os ministros Gilmar Mendes (Twitter, desde 2017), Alexandre de Moraes (Twitter, desde 2017) e Luís Roberto Barroso (Twitter e Instagram, desde 2020). Entre os ministros aposentados, possuem contas Joaquim Barbosa (Twitter, desde 2014) e Ayres Britto (Twitter, desde 2018).

${ }^{24}$ A preocupação com as discussões travadas em redes sociais parece ser ainda mais perceptível na definição da pauta de julgamentos.
} 


\section{Antigos ministros: algo mudou?}

Como mencionado no início deste artigo, as entrevistas conduzidas seguiram um modelo que costuma ser chamado de "entrevistas estruturadas", ou seja, entrevistas iguais para todos os participantes. Uma pequena exceção ocorria ao fim das entrevistas com os ministros aposentados. A estes, quando havia tempo (infelizmente nem sempre havia) era perguntado se o STF havia mudado desde o momento em que eles haviam saído do tribunal. Embora não haja dúvidas de que essa é uma pergunta muito genérica e, mais do que isso, que pode servir apenas como gatilho para o recorrente, e também genérico, discurso "na minha época era melhor", o fato é que algumas das respostas suscitaram comentários específicos acerca de mudanças consideradas problemáticas pelos antigos ministros. Em alguns casos, a alegada mudança tinha a ver mais com o papel do STF no sistema político-constitucional brasileiro do que com atitudes pessoais dos ministros. E, mais importante, houve quem tenha apontado mudanças para melhor, fugindo da armadilha do saudosismo.

Entre aqueles que apontaram mudanças, a maioria mencionou uma deterioração nas relações pessoais entre os integrantes do tribunal:

Sempre houve muita cordialidade. [...] O Supremo era tido como um colegiado em que não existia o "presidencialismo". [Muitas] decisões eram [discutidas] em sessões administrativas. Isso acontecia no TSE também. Quando eu presidi, nós tínhamos sessões administrativas todos os dias. [...] O Supremo sempre teve um sistema de colegiado, [...] não presidencial. E, como observador externo, eu acho que mudou. Não sei se essa minha observação é procedente, mas veja como foi marcante a presidência do Joaquim [Barbosa]. Esse é um dos motivos que me levam a pensar que mudou. (ministro O)

Eu acho que realmente a cordialidade do trato caiu. Não quero individualizar, mas tem havido uma inadequação do latim na presidência do colegiado... Isso tem um efeito na instituição. [Além disso,] a falta de vigilância na circulação de fotógrafos possibilitou aquela verdadeira violação de correspondência... ${ }^{25}$ Aquilo intimidou [a ministra Cármen Lúcia] e a fez muito menos incisiva nos debates. Juridicamente, foi uma violação de correspondência. (ministro P)

\footnotetext{
${ }^{25}$ Em agosto de 2007, na primeira sessão do julgamento da Ação Penal 470 (mensalão), fotógrafos de veículos de imprensa tiraram fotos da tela do computador da ministra Cármen Lúcia Antunes Rocha e revelaram trechos de um diálogo com o ministro Lewandowski.
} 
Mas, como salientado no início deste tópico, nem todas as mudanças apontadas têm a ver com a postura dos ministros. O ministro $Q$, por exemplo, sublinhou o protagonismo do STF, e suas consequências na carga de trabalho, na relação com outros poderes como a principal mudança desde a sua passagem pelo tribunal:

O STF se tornou um ícone, coisa que ele não era à vista do grande público.

O regime de trabalho se agravou. Ele não era tão cruel como é hoje. [...] Nunca houve, em parte alguma deste planeta, em momento algum da história e, destacadamente, não há neste momento da história nada que nos iguale muito menos supere em matéria de prerrogativa judiciária, em matéria daquilo que os franceses ironicamente chamam "governo dos juízes”. Nós assimilamos o modelo norte-americano, que é minoritário no mundo, e levamos às últimas consequências. Não conhecemos o conceito de questão política, não jurisdicionável. Aqui, tudo é jurisdicionável! Várias das limitações que a Suprema Corte [dos Estados Unidos] tem o Supremo brasileiro não tem. (ministro Q)

Apenas o ministro $\mathrm{S}$ abordou de forma específica uma mudança na forma de deliberar. Sem saudosismo, apontou que nem todas as mudanças são negativas:

No meu tempo, pelo menos no começo, primeiro falava o relator, depois falava o menos antigo, às vezes alguém se antecipava e começava a debater. Hoje, nem se dirige ao presidente, [...] às vezes há até um diálogo. Eu não sei qual o melhor, sinceramente. Vejo aspectos positivos e negativos, [...] porque muita formalidade também inibe [a deliberação]. (ministro S)

\section{Conclusão}

Não é tarefa simples concluir um artigo com tantos temas distintos, construído a partir das opiniões de quase duas dezenas de ministros. Ao contrário do que ocorre com os temas abordados nos outros artigos da série, ${ }^{26}$ os quais tinham uma relação razoavelmente clara com a prática deliberativa do tribunal, os temas deste artigo não suscitavam nos ministros, ao menos não imediatamente, o estabelecimento de uma conexão com o que ocorre nas sessões de julgamento. Ainda assim, o debate sobre todos eles foi extremamente frutífero, para confirmar ou infirmar algumas visões mais intuitivas sobre legitimidade do controle judicial de constitucionalidade, o papel dos métodos de interpretação constitucional ou a relação do tribunal com seu público externo, por exemplo.

${ }^{26} \mathrm{Cf}$. os artigos citados na nota 4. 
A maior amplitude temática deste artigo também dificulta a identificação de tendências nas respostas dos ministros. Não foi possível observar divisões claras ou antagonismos entre grupos de ministros.

A conclusão que me parece mais frutífera está ligada a um fator que poderia inicialmente ser considerado um problema do artigo: a passagem do tempo entre a realização das entrevistas e a publicação do texto. Essa passagem do tempo tornou possível avaliar de que maneira ideias embrionárias, explícitas ou implícitas em muitas das respostas dos ministros, se desenvolveram posteriormente, de forma exitosa ou não.

Além disso, a distância entre o momento das entrevistas e a publicação do texto permite avaliar o impacto de mudanças que, embora não estivessem presentes, nem mesmo de forma embrionária, nas respostas dos ministros, provocaram alterações relevantes não apenas na deliberação em geral mas também nas variáveis específicas analisadas neste artigo.

Uma primeira mudança, explicitamente sugerida pelo ministro E, diz respeito àquilo que hoje o tribunal chama de teses. Reproduzo aqui o trecho mais pertinente:

Eu sou a favor [...] de que, ao final da votação, o relator para o acórdão produza uma ementa na qual fique explicitado qual foi a tese jurídica do acórdão, [...] e esta ementa deve ser aprovada pela maioria que se formou. (ministro E)

No momento das entrevistas, algo semelhante a essa proposta existia apenas na edição de súmulas vinculantes e na análise da repercussão geral em recursos extraordinários. A proposta do ministro E era transformar essa prática limitada em processo decisório padrão do tribunal. Embora não haja qualquer base constitucional ou legal para tanto (cf. SILVA, 2021, p. 581), a definição de teses tem se tornado cada vez mais frequente nas decisões dos mais variados tipos de ações e recursos. Como já foi mencionado, ${ }^{27}$ trata-se de uma tentativa de introduzir algo semelhante a uma “opinião da corte”, existente em tribunais de outros países, em um processo decisório extremamente individualizado como o do STF. Mas ela vai além, porque a existência de uma opinião da corte, não importa se definida de forma unânime ou majoritária, não tem relação necessária com o tipo de decisão e com a força vinculante das razões de decidir. Em outras palavras, nem toda “opinião da corte” contém uma tese jurídica de caráter geral e abstrato.

${ }^{27}$ Cf. nota 6. 
Ainda são necessárias mais pesquisas para avaliar o impacto das teses jurídicas na deliberação do tribunal e em seu processo decisório. ${ }^{28}$ Embora o ministro E tenha feito menção a elas quando do debate sobre a legitimidade do tribunal, porque, segundo ele, decisões que produzem teses jurídicas são mais claras e institucionalmente coesas, o que fomentaria essa legitimidade, é certo que elas podem ter também um forte impacto em outra variável analisada aqui, o sistema de precedentes do tribunal.

Menos exitosas foram as sugestões de alteração na dinâmica das audiências públicas e na definição da pauta de julgamentos.

Sobre as audiências públicas, a crítica mais recorrente permanece inteiramente válida: em geral, apenas a ministra ou o ministro relator comparece, o que certamente relativiza sua importância e seu impacto na deliberação. Se, em um colegiado com onze membros, apenas um participou da audiência pública sobre determinado caso, é possível afirmar que seu impacto na deliberação é limitado. Para além da questão relativa à baixa participação dos ministros, o ministro $\mathrm{F}$ apontou a forma de funcionamento dos trabalhos nas audiências como um limitador de seu potencial:

A audiência pública é realizada [...] na forma de sustentação oral. O sentido de audiência pública na cultura binária jurídica brasileira tem que ser modificado. Não é vir alguém à tribuna sustentar a sua posição por dez, quinze, vinte minutos e ir embora, aí vem outro [e faz o mesmo]. No dia em que eu chamar uma audiência pública, [...] eu vou colocar "eu quero ficar ouvindo vocês por três horas, um pegando o outro”. Vamos ver "você fala que a vida acaba em tal lugar, você fala que vida acaba aqui...". Vamos ouvir o debate. Deixa ali solto, sem formalismo, sem formalismo. (ministro F)

Tem havido tentativas de fazer algo semelhante a essa proposta. As audiências convocadas pela ministra Rosa Weber são o melhor exemplo. No cronograma de todas elas, ${ }^{29}$ havia a previsão de um espaço "deliberativo" ou "dialogal”. ${ }^{30}$ Não é possível fazer aqui uma análise detalhada dessa nova prática, porque este não é um artigo específico sobre audiências públicas. ${ }^{31}$ Ainda assim é importante apontar fatores que podem indicar que as mudanças foram apenas marginais. Em primeiro

\footnotetext{
${ }^{28}$ Essa transformação do padrão decisório do STF ainda não despertou muito o interesse da literatura constitucional brasileira. Uma exceção importante são alguns trabalhos de Cani $(2017,2019)$.

${ }^{29}$ ADI 5.527 (2017), ADPF 442 (2018), ADO 59 (2020).

${ }^{30}$ Em algumas audiências convocadas por outros ministros também houve previsões semelhantes. Cf., por exemplo, ADC 51 (2020), convocada pelo ministro Gilmar Mendes, e ADI 5.624 (2018), convocada pelo ministro Ricardo Lewandowski.

${ }^{31}$ Para essa análise, cf. por exemplo, Guimarães (2020).
} 
lugar, porque o cerne das audiências continua a ser as longas séries de breves palestras individuais, em parte proferidas por juristas. Em segundo lugar, porque ao "espaço deliberativo" costuma ser reservado um tempo muito reduzido, em geral vinte a trinta minutos, ao final de um longo dia ocupado por dezenas de palestras. Por fim, porque o "espaço deliberativo" - para o qual nenhum edital definiu regras de funcionamento e de uso da palavra - pode ser instrumentalizado para abrir mais tempo de fala a determinados expositores ou se transformar em espaço para o simples esclarecimento de dúvidas do relator.

$\mathrm{O}$ próprio ministro $\mathrm{F}$ - que fez a veemente crítica à estrutura rígida das audiências e prometeu romper com esse modelo - talvez tenha deixado de crer em seu potencial deliberativo. Embora tenha convocado audiências desde então, elas seguiram estritamente o modelo "série de palestras".

Por fim, também em relação à definição da pauta houve tentativas de combater os problemas mencionados pelos ministros e de implantar algumas das mudanças suscitadas. Como foi visto, sobre essa questão o ministro D afirmou:

O ideal seria [...] que se fizesse uma pauta semestral ou algo assim." (ministro D)

Há ao menos duas formas de entender a expressão "pauta semestral" e não é possível saber a qual delas o ministro $\mathrm{D}$ fez referência. Pauta semestral pode significar a definição, no início de um semestre, das ações que serão impreterivelmente julgadas no período. Nessa acepção, não seria possível deixar para o semestre seguinte o julgamento de uma ação previsto para ocorrer no semestre atual. Por essa concepção de pauta semestral, não é necessário que se defina, no início do semestre, os dias exatos em que ocorrerão os julgamentos de cada ação. Pauta, nesse caso, não tem um sentido de agenda detalhada, mas de seleção dos casos a serem necessariamente julgados.

A segunda acepção de pauta semestral tem características opostas às da primeira. Ela é uma agenda detalhada dos julgamentos previstos para o semestre, mas não impede que um julgamento seja adiado para o semestre seguinte ou mesmo para momento indeterminado.

A pauta semestral que existe hoje no STF é desse segundo tipo. De um lado, portanto, ela parcialmente resolve um problema apontado por vários ministros $(\mathrm{A}, \mathrm{H}$, B, E e D), todos na ativa no momento das entrevistas, que era a falta de tempo para se preparar para a deliberação. Mas, como sublinhado, o problema é resolvido apenas parcialmente, porque a discricionariedade da presidência do tribunal na composição da pauta permanece. Isso não significa apenas que a questão política do controle da agenda do tribunal não foi alterada, mas também que processos que estavam pautados 
para o semestre podem sair da pauta sem aviso prévio e processos que não estavam pautados podem entrar. Diante disso, a crítica do ministro I permanece válida:

Às vezes eu tenho uma pauta que eu estudei de noite e chego de manhã antes da sessão e [me dizem]: “ministro, caíram tais, tais e tais processos”... Eu me dediquei a noite inteira para estudar um processo e entra outro no lugar. Isso é errado, isso é ruim. (ministro I)

A maior mudança na definição da pauta de julgamentos foi na verdade introduzida por uma transformação que não parecia estar no horizonte de nenhum ministro: a rápida expansão da competência para julgamentos realizados em ambiente eletrônico, também conhecido como plenário virtual. Embora existisse desde 2007, não parecia que o plenário virtual tivesse, na época das entrevistas, potencial para ocupar o espaço dos ambientes físicos e presenciais (o pleno e as turmas) nos julgamentos de casos importantes. Ao contrário, o plenário virtual era encarado como uma forma de desafogar o pleno e as turmas para que pudessem se concentrar justamente nas decisões mais importantes.

Contudo, a história do plenário virtual nos últimos anos seguiu caminho distinto e sua expansão atingiu o ápice com a pandemia de covid-19. A Emenda Regimental 53/2020 alterou o art. 21-B do Regimento Interno do STF para permitir que qualquer processo possa ser julgado no plenário virtual. Sua pauta de julgamentos é construída de forma muito distinta daquelas dos ambientes físicos e presenciais. Nela, o poder da presidência é mitigado, porque os processos são julgados na sequência em que são liberados pelos respectivos relatores.

Não se sabe ainda ao certo se essa expansão do plenário virtual é conjuntural, apenas em razão da pandemia de covid-19, ou se será mantida mesmo depois que as medidas de isolamento social forem relaxadas. Se for mantida, é possível afirmar que esta será muito provavelmente a maior transformação na prática deliberativa do STF em tempos recentes. Seus efeitos vão muito além da mudança na forma de definição da pauta. A interação entre ministros, que já não era intensa nos ambientes físicos e presenciais, é praticamente inexistente no plenário virtual. A fragmentação argumentativa e decisória tende a ficar ainda mais aguda.

Em suma, caso o tribunal não reveja a expansão dos julgamentos em ambiente virtual, a ideia de deliberação que serviu de base às entrevistas e aos artigos com os resultados da pesquisa, centrada na troca de argumentos e na possibilidade de se deixar convencer pelos argumentos dos colegas, ${ }^{32}$ provavelmente tenderá a desaparecer, e um dos principais problemas do processo decisório do STF, o seu extremo individualismo, provavelmente será ainda mais reforçado.

${ }^{32}$ Cf. tópico 3. 


\section{Referências}

ARGUELHES, Diego Werneck; HARTMANN, Ivar A. Timing control without docket control: how individual justices shape the Brazilian Supreme Court's Agenda. Journal of Law and Courts, v. 5, n. 1, p. 105-140, 2017.

CANI, Julia Wand-Del-Rey. Supremo: um tribunal (só) de teses? In: ARGUELHES, Diego Werneck; FALCÃO, Joaquim; RECONDO, Felipe. (ed.). Onze supremos: o Supremo em 2016. Belo Horizonte: Letramento: Casa do Direito: Jota: Supra: FGV Direito Rio, 2017. p. 113-115.

CANI, Julia Wand-Del-Rey. Para onde foram as “teses” no Supremo? In: FALCÃO, Joaquim et al. (ed.). O Supremo e o processo eleitoral. Belo Horizonte: Letramento: Casa do Direito: Jota: Supra: FGV Direito Rio, 2019. p. 51-54.

ESTEVES, Luiz Fernando Gomes. Onze ilhas ou uma ilha e dez ilhéus?: a presidência do STF e sua influência na atuação do tribunal. Revista Estudos Institucionais, v. 6, n. 1, p. $129-154,2020$.

FALCÃO, Joaquim; OLIVEIRA, Fabiana Luci de. O STF e a agenda pública nacional: de outro desconhecido a supremo protagonista? Lua Nova: revista de cultura e política, n. 88, p. 429469, 2013. Disponível em: http://cedec.org.br/constituicao-e-processo-constituinte---no88--ano-2013. Acesso em: 24 jun. 2021.

GUIMARÃES, Lívia Gil. Participação social no STF: repensando o papel das audiências públicas. Revista Direito e Práxis, v. 11, n. 1, p. 236-271, 4 mar. 2020.

KRANENPOHL, Uwe. Die Bedeutung von Interpretationsmethoden und Dogmatik in der Entscheidungspraxis des Bundesverfassungsgerichts. Der Staat, v. 48, n. 3, p. 387-409, 2009a.

KRANENPOHL, Uwe. Die gesellschaftlichen Legitimationsgrundlagen der Verfassungsrechtsprechung oder: Darum lieben die Deutschen Karlsruhe. Zeitschrift für Politik, v. 56, n. 4, p. 436-453, 2009b.

KRANENPOHL, Uwe. Herr des Verfahrens oder nur Einer unter Acht? Der Einfluss des Berichterstatters in der Rechtsprechungspraxis des Bundesverfassungsgerichts. Zeitschrift für Rechtssoziologie, v. 30, n. 2, p. 135-163, 2009c.

KRANENPOHL, Uwe. Hinter dem Schleier des Beratungsgeheimnisses. Wiesbaden: VS Verlag für Sozialwissenschaften, 2010.

KRUMPAL, Ivar. Determinants of social desirability bias in sensitive surveys: a literature review. Quality \& Quantity, v. 47, n. 4, p. 2025-2047, 19 nov. 2011.

SILVA, Virgílio Afonso da. Interpretação constitucional e sincretismo metodológico. In: SILVA, Virgílio Afonso da. (ed.). Interpretação constitucional. São Paulo: Malheiros, 2005. p. $115-143$. 
SILVA, Virgílio Afonso da. Deciding without deliberating. International Journal of Constitutional Law, v. 11, p. 557-584, 2013.

SILVA, Virgílio Afonso da. "Um voto qualquer”?: o papel do ministro relator na deliberação no Supremo Tribunal Federal. Revista Estudos Institucionais, v. 1, n. 1, p. 180-200, 2015 a.

SILVA, Virgílio Afonso da. De quem divergem os divergentes: os votos vencidos no Supremo Tribunal Federal. Direito, Estado e Sociedade, v. 47, p. 205-225, 2015 b.

SILVA, Virgílio Afonso da. O relator dá voz ao STF?: uma réplica a Almeida e Bogossian. Revista Estudos Institucionais, v. 2, n. 2, p. 648-669, 2016.

SILVA, Virgílio Afonso da. Do we deliberate? If so, how? European Journal of Legal Studies, v. 9, n. 2, p. 209-240, 2017.

SILVA, Virgílio Afonso da. Big Brother is watching the court: effects of TV broadcasting on judicial deliberation. Verfassung und Recht in Übersee, v. 51, n. 2, 2018.

SILVA, Virgílio Afonso da. Direito constitucional brasileiro. São Paulo: Edusp, 2021.

\section{Jurisprudência citada}

BRASIL. Supremo Tribunal Federal. Ação Declaratória de Constitucionalidade 51/ DF. Relator: Ministro Gilmar Mendes. Andamento processual disponível em: https:// portal.stf.jus.br/processos/detalhe.asp?incidente $=5320379$. Acesso em: 4 jun. 2021 (sem julgamento até a presente data).

BRASIL. Supremo Tribunal Federal. Ação Direta de Inconstitucionalidade 5.527/DF. Relatora: Ministra Rosa Weber. Andamento processual disponível em: https://portal.stf. jus.br/processos/detalhe.asp?incidente=4983282. Acesso em: 4 jun. 2021 (sem julgamento até a presente data).

BRASIL. Supremo Tribunal Federal. Ação Direta de Inconstitucionalidade 5.624/DF. Relator: Ministro Ricardo Lewandowski. Andamento processual disponível em: https:// portal.stf.jus.br/processos/detalhe.asp?incidente=5093069. Acesso em: 4 jun. 2021 (sem julgamento até a presente data).

BRASIL. Supremo Tribunal Federal. Ação Direta de Inconstitucionalidade por Omissão 59/DF. Relatora: Ministra Rosa Weber. Andamento processual disponível em: https:// portal.stf.jus.br/processos/detalhe.asp?incidente=5930766. Acesso em: 4 jun. 2021 (sem julgamento até a presente data).

BRASIL. Supremo Tribunal Federal. Arguição de Descumprimento de Preceito Fundamental 442/DF. Relatora: Ministra Rosa Weber. Andamento processual disponível em: https://portal.stf.jus.br/processos/detalhe.asp? incidente=5144865. Acesso em: 4 jun. 2021 (sem julgamento até a presente data). 


\section{Legislação citada}

BRASIL. [Constituição (1988)]. Constituição da República Federativa do Brasil de 1988. Brasília: Presidência da República, [2021]. Disponível em: https://www.planalto.gov.br/ccivil_03/ Constituicao/Constituicao.htm. Acesso em: 14 abr. 2021.

BRASIL. Lei no $\mathbf{9 . 8 6 8}$, de 10 de novembro de 1999. Dispõe sobre o processo e julgamento da ação direta de inconstitucionalidade e da ação declaratória de constitucionalidade perante o Supremo Tribunal Federal. Brasília: Presidência da República, [2009]. Disponível em: https://www.planalto.gov.br/ccivil_03/leis/19868.htm. Acesso em: 14 abr. 2021.

\section{Anexo:}

\section{Questionário}

\section{Qualidade das decisões e legitimidade}

Ao contrário do que ocorre em países como os Estados Unidos, no Brasil o controle judicial de constitucionalidade é previsto pela própria Constituição. Isso afasta uma série de críticas à legitimidade do STF no exercício desse controle. Ainda assim, há quem afirme que a legitimidade de um tribunal é tanto maior quanto maior for a qualidade de suas decisões. Qual é sua opinião a respeito?

Você pensa que a atual forma de deliberação, decisão e publicação de decisões do tribunal fomenta a qualidade das decisões?

A atual forma de deliberação, decisão e publicação de decisões do tribunal tem gerado, em alguns casos, decisões extremamente longas (o caso mais conhecido é a decisão Raposa/Serra do Sol). Essas decisões são uma soma dos votos dos ministros. Essa forma de publicação afeta a qualidade da decisão?

\section{Pauta}

Na sua opinião, a pauta das sessões de julgamento do STF é divulgada com a devida antecedência?

[em caso negativo] A divulgação da pauta sem a devida antecedência tem influência na qualidade da deliberação e do julgamento?

[em caso afirmativo] Não é difícil se preparar para um julgamento com poucos dias de antecedência? 


\section{Princípios e métodos de interpretação}

Nos últimos anos, princípios e métodos de interpretação constitucional têm sido amplamente debatidos no mundo acadêmico, com destaque para o chamado princípio da proporcionalidade. Na sua opinião, qual é o papel desses métodos nas atividades do Supremo Tribunal Federal e na deliberação entre os ministros?

$\mathrm{O}$ fato de os ministros votarem individualmente permite que cada um utilize o método de interpretação e aplicação da Constituição que entender mais adequado. Isso pode gerar alguma dificuldade no diálogo entre os ministros?

\section{Precedentes}

Na sua opinião, a atual forma de deliberação e publicação de votos no STF permite a construção de um sistema de precedentes?

O fato de termos a soma de onze votos pode dificultar a identificação das razões de decidir, especialmente se os votos que compõem a maioria tiverem fundamentos diferentes para a mesma tese?

\section{Audiências públicas}

A experiência recente de audiências públicas teve algum papel nas decisões dos respectivos casos já decididos? Elas têm algum papel no convencimento dos ministros? Você teria algum exemplo pessoal?

\section{Opinião pública}

Ao escrever seus votos, você pensa apenas na decisão do caso? Ou pensa também no impacto que eles podem ter em outros âmbitos? [exemplos de outros âmbitos: academia, poderes políticos, economia] 